\title{
Mometasone furoate is a less specific glucocorticoid than fluticasone propionate
}

\author{
R.J.H. Austin*, B. Maschera*, A. Walker", L. Fairbairn*, E. Meldrum*, S.N. Farrow*, I.J. Uings*
}

Mometasone furoate is a less specific glucocorticoid than fluticasone propionate. R.J.H. Austin, B. Maschera, A. Walker, L. Fairbairn, E. Meldrum, S.N. Farrow, I.J. Uings. (C) ERS Journals Ltd 2002.

ABSTRACT: Fluticasone propionate (FP) and mometasone furoate (MF) are potent synthetic corticosteroids that are widely used as anti-inflammatory agents to treat respiratory diseases. As part of the assessment of the potential for side-effects associated with their use, their activities, not only at the glucocorticoid receptor (GR) but also at the other members of the steroid nuclear receptor family, have been compared.

Cell-based functional systems were established to measure different aspects of GR function, as well as the activity at all the other steroid nuclear receptors.

The effects of MF and FP on the GR were potent and indistinguishable. Neither corticosteroid showed any activity at the oestrogen receptor, while both were weak antagonists of the androgen receptor. FP was a relatively weak agonist of the progesterone receptor but MF was a very potent agonist of the progesterone receptor, giving activity at similar concentrations to those that stimulate the GR (concentration generating $50 \%$ maximal effect $(E C 50)=50 \mathrm{pM})$. Moreover, while $\mathrm{FP}$ was a weak antagonist of the mineralocorticoid receptor (concentration generating $50 \%$ maximal inhibitory effect $=80 \mathrm{nM})$, MF displayed potent partial agonist activity $(\mathrm{EC} 50=3 \mathrm{nM}$, $30 \%)$.

Mometasone furoate is considerably less specific for the glucocorticoid receptor than fluticasone propionate, showing significant activity at other nuclear steroid receptors. Eur Respir J 2002; 20: 1386-1392.
Depts of *Asthma Cell Biology and ${ }^{\#}$ Gene Expression and Protein Biochemistry, GlaxoSmithKline, Stevenage, Hertfordshire, UK.

Correspondence: I. Uings

Dept of Asthma Cell Biology

GlaxoSmithKline

Stevenage

Hertfordshire

SG1 2NY

UK

Fax: 441438764782

E-mail: iain.j.uings@gsk.com

Keywords: Asthma

corticosteroid

fluticasone

mineralocorticoid

mometasone

progesterone

Received: December 52001

Accepted after revision: July 252002
In recent decades, topically applied synthetic corticosteroid drugs have become, for many, the drug of choice used to control the chronic inflammation that characterises conditions such as asthma and allergic rhinitis [1]. While the clinical efficacy of agents such as budesonide and beclomethasone is well established, a number of side-effects have been associated with long-term use of high-dose inhaled corticosteroids. These include reduction in bone mineral density [2], slowing of growth [3], appearance of skin bruising [4], development of cataracts [5] and dysregulation of blood glucose control mechanisms [6], and result from systemic exposure to the corticosteroid despite topical administration. Attempts to minimise the potential for such side-effects have led to the development of a new generation of corticosteroid drugs that display not only increased potency but also faster clearance rates from the systemic circulation. Forefront among this new generation of corticosteroids are fluticasone propionate (FP) [7] and mometasone furoate (MF) [8, 9], and these agents are now being widely promoted for use in both intranasal and inhaled formulations to treat a number of inflammatory disorders of the respiratory tract $[10,11]$.

Corticosteroids exert their actions through the glucocorticoid receptor (GR) [12], which is a member of a family of nuclear steroid receptors that includes the progesterone receptor, the oestrogen receptors, the mineralocorticoid receptor and the androgen receptor [13]. These receptors are closely related in structure, and many synthetic ligands can bind to more than one receptor. Under resting conditions, GR exists in a cytosolic complex that includes the chaperone protein heat shock protein (hsp)90 [14]. Following ligand binding, the receptor is released from the hsp90 complex and rapidly translocates into the nucleus where, like other nuclear receptors, it modulates gene expression by binding to distinct deoxyribonucleic acid (DNA) elements within gene promoters. These glucocorticoid response elements (GREs) take the form of imperfect palindromes to which the receptor binds as a homodimer and acts as a transcription factor. However in recent years it has become clear that GR can also regulate gene expression from promoters that lack any GRE through direct interaction with other transcription factors including nuclear factor (NF)- $\mathrm{B}$ [15], activating protein (AP)-1 [16] and members of the signal transducer and activator of transcription STAT family [17, 18]. Many of the genes regulated by NF- $\mathrm{KB}$ and AP-1 are intimately involved in the inflammatory response, and it is the repression of the activity of these transcription factors that is believed to be the 
principle mechanism underlying the anti-inflammatory efficacy of corticosteroids [19, 20].

Attempts to compare the cellular activities of FP and MF have consistently failed to distinguish between the molecules $[11,21,22]$. Therefore, the pharmacology of these important corticosteroids was compared in a number of cell-based functional assays designed to measure not only GR function but also the activity of other related nuclear steroid receptors.

\section{Materials and methods}

\section{Cell lines}

All parental cell lines were obtained from the European Collection of Cell Cultures. COS-1 cells (monkey kidney fibroblasts) and T47D cells (human breast carcinoma) were cultured in Dulbecco's Modified Eagle Medium (DMEM) supplemented with $10 \%$ foetal calf serum (FCS), $0.1 \mathrm{U} \cdot \mathrm{mL}^{-1}$ penicillin, $0.1 \mu \mathrm{g} \cdot \mathrm{mL}^{-1}$ streptomycin, $2 \mathrm{mM}$ glutamine, and nonessential amino acids $(1 \times)$. Ishikawa cells (human endometrial adenocarcinoma) were grown in phenol red-free DMEM supplemented as above. A549 (human lung epithelial carcinoma)-derived reporter cell lines were routinely maintained in DMEM supplemented as above, containing $0.5 \mathrm{mg} \cdot \mathrm{mL}^{-1}$ of the antibiotic G418 (geneticin) to maintain selection pressure.

\section{Construction of reporter gene cell lines}

Reporter gene constructs. The long terminal repeat of the mouse mammary tumour virus (MMTV-LTR) driven renilla luciferase reporter construct was generated by a three-way ligation of a HindIII/BamHI fragment of pRL-Null vector (Promega Corp., Madison, WI, USA) containing the renilla luciferase gene, minimal promoter and a $3^{\prime}$ untranslated region derived from the SV40 virus, a MunI/HindIII fragment of the MMTVLTR containing the steroid response elements and a BamHI/MunI fragment of pcDNA3 vector (Invitrogen, Groningen, the Netherlands) containing the neomycin and ampicillin selection markers, but not the strong cytomegalovirus (CMV) promoter element.

The firefly luciferase gene driven by a promoter containing five copies of the NF-KB consensus sequence (GGGGACTTTCC) was derived from the pNF-кB-Luc plasmid (Stratagene, La Jolla, CA, USA) using NdeI and StyI restriction enzymes. It was then subcloned into the pcDNA3 vector and the CMV promoter was deleted using NdeI and XbaI restriction enzymes, in order to generate the construct p5NF-кB-firefly-neo.

The MMTV-secreted placental alkaline phosphatase (sPAP) construct contained the secreted placental alkaline phosphatase gene under the control of the entire MMTV-LTR, and was a kind gift from D. Wallace (GlaxoSmithKline, Stevenage, UK).

Generation of the reporter cell lines. A549 cells were transfected either by electroporation $(\mathrm{NF}-\kappa \mathrm{B}$ reporter, $25 \mu \mathrm{g}$ DNA, $1 \times 10^{7}$ cells per transfection at $960 \mu \mathrm{F}$ and
$250 \mathrm{~V}$ ) or by using lipofectamine 2000 (MMTV reporter; Life Technologies, Paisley, UK). Stably transfected cells were selected based on the acquisition of antibiotic resistance by the addition of $1 \mathrm{mg} \cdot \mathrm{mL}^{-1} \mathrm{G} 418$ to the culture media and the resulting clones were isolated, by ring cloning, and screened for activity. A single clone for each reporter was chosen and maintained.

\section{Glucocorticoid receptor-mediated gene transactivation}

The A549-MMTV-LTR reporter cells were seeded into a white 96 -well plate at a density of $4 \times 10^{4}$ cells per well and grown overnight at $37^{\circ} \mathrm{C}$. The steroids were dissolved in dimethylsulphoxide (DMSO) and added to the cells to give a final DMSO concentration of $0.7 \%$. After 16 -h incubation at $37^{\circ} \mathrm{C}$ the medium was removed and the cells washed into phosphatebuffered saline (PBS) containing $1 \mathrm{mM} \mathrm{CaCl} 2$ and $1 \mathrm{mM} \mathrm{MgCl} 2$. Renilla luciferase activity was detected using the Firelite kit (Packard, Pangbourne, UK) according to the manufacturer's protocol.

Glucocorticoid receptor-mediated transrepression of nuclear factor- $\kappa$ B activity

The A549-NF- $\kappa$ B reporter cells were seeded into a white 96-well plate at a density of $4 \times 10^{4}$ cells per well and grown overnight at $37^{\circ} \mathrm{C}$. The steroids were dissolved in DMSO and added to the cells to give a final DMSO concentration of $0.7 \%$. One hour later, cells were stimulated with $0.5 \mathrm{ng} \cdot \mathrm{mL}^{-1}$ tumour necrosis factor (TNF)- $\alpha$ (R\&D Systems, Abingdon, UK). After $16-\mathrm{h}$ incubation at $37^{\circ} \mathrm{C}$ the medium was removed and the cells washed into PBS containing $1 \mathrm{mM} \mathrm{CaCl} 2$ and $1 \mathrm{mM} \mathrm{MgCl}_{2}$. Firefly luciferase activity was detected using the Luclite kit (Packard) according to the manufacturer's protocol.

\section{Progesterone receptor-mediated gene transactivation}

The human breast cancer cell line T47D has been reported to upregulate an endogenous alkaline phosphatase in response to progestins [23]. T47D cells were seeded into 96-well plates at a density of $1 \times 10^{5}$ cells per well and grown overnight at $37^{\circ} \mathrm{C}$. Steroids were dissolved in DMSO, added to the cells (final DMSO concentration $0.7 \%$ ), and incubated for $24 \mathrm{~h}$ at $37^{\circ} \mathrm{C}$. The cells were then washed with PBS and lysed with RIPA buffer ( $1 \%$ Igepal, $0.5 \%$ sodium deoxycholate, $0.1 \%$ sodium dodecylsulphate in PBS). Alkaline phosphatase activity was measured spectrophotometrically $(405 \mathrm{~nm})$ using p-nitrophenylphosphate $\left(1.5 \mathrm{mg} \cdot \mathrm{mL}^{-1}\right)$ as a substrate, dissolved in $1 \mathrm{M}$ diethanolamine, $0.28 \mathrm{M} \mathrm{NaCl}$ and $0.5 \mathrm{mM}$ magnesium chloride.

\section{Oestrogen receptor-mediated gene transactivation}

The human endometrial adenocarcinoma cell line, Ishikawa, has been reported to upregulate an 
endogenous alkaline phosphatase in response to oestrogens [24]. The procedure was identical to that for the progesterone receptor assay, except that the cells were seeded at a density of $4 \times 10^{4}$ cells per well, and were treated with steroids in the absence of FCS. To investigate anti-oestrogenic effects of steroids, the corticosteroid was added to the cells 15 min prior to the addition of $5 \mathrm{pM}$ oestradiol (a concentration that elicits $80 \%$ of the maximal response to oestradiol) and the assay was carried out as described above.

\section{Mineralocorticoid and androgen receptor-mediated gene transactivation}

A flask of COS-1 cells was cotransfected with a reporter plasmid containing the sPAP under the control of the MMTV-LTR and a plasmid encoding expression of either human mineralocorticoid receptor or human androgen receptor using lipofectamine 2000 according to the manufacturer's protocol. Twentyfour hours after transfection, the cells were seeded into a 96-well plate and incubated at $37^{\circ} \mathrm{C}$ for $6 \mathrm{~h}$. Steroids were dissolved in DMSO and added to the cells to give a final DMSO concentration of $0.7 \%$. After 16 -h incubation at $37^{\circ} \mathrm{C}$, medium was harvested, heat-inactivated for $15 \mathrm{~min}$ at $65^{\circ} \mathrm{C}$ and assayed for sPAP activity spectrophotometrically (405 nm) using p-nitrophenylphosphate $\left(1.5 \mathrm{mg} \cdot \mathrm{mL}^{-1}\right)$ as a substrate, dissolved in $1 \mathrm{M}$ diethanolamine, $0.28 \mathrm{M} \mathrm{NaCl}$, $0.5 \mathrm{mM} \mathrm{MgCl}$. To investigate the antimineralocorticoid or anti-androgen effects of steroids, the corticosteroid was added to the cells $15 \mathrm{~min}$ prior to the addition of $1 \mathrm{nM}$ aldosterone or $6 \mathrm{nM}$ testosterone (concentrations that elicit $80 \%$ of the maximal response in each case) and the assay carried out as described above.

\section{Results}

The MMTV-LTR contains a number of steroid response elements that potentially can be stimulated by all of the steroid receptors. In stably transfected A549 lung epithelial cells, dexamethasone stimulated a 5.1 \pm 0.7 -fold increase in MMTV-LTR reporter gene expression with a concentration generating 50\% maximal effect (EC50) of 8nM (fig. 1a). However, steroid ligands specific for all the other steroid nuclear receptors failed to stimulate reporter gene expression (i.e. progesterone, oestradiol, aldosterone and testosterone; data not shown), indicating that the only active steroid receptor in these cells is GR. The new generation corticosteroids FP and MF, were both more than two orders of magnitude more potent than dexamethasone, giving EC50 values of $25 \mathrm{pM}$ and $20 \mathrm{pM}$, respectively (fig. 1a). Although MF reached the same maximal response as dexamethasone, high concentrations of FP consistently stimulated a moderately higher level of reporter gene expression $(144 \pm 14 \%, \mathrm{p}<0.01)$.

Next, the ability of the corticosteroids to transrepress the activity of the pro-inflammatory transcription factor NF- $\mathrm{KB}$ was examined using an A549 cell
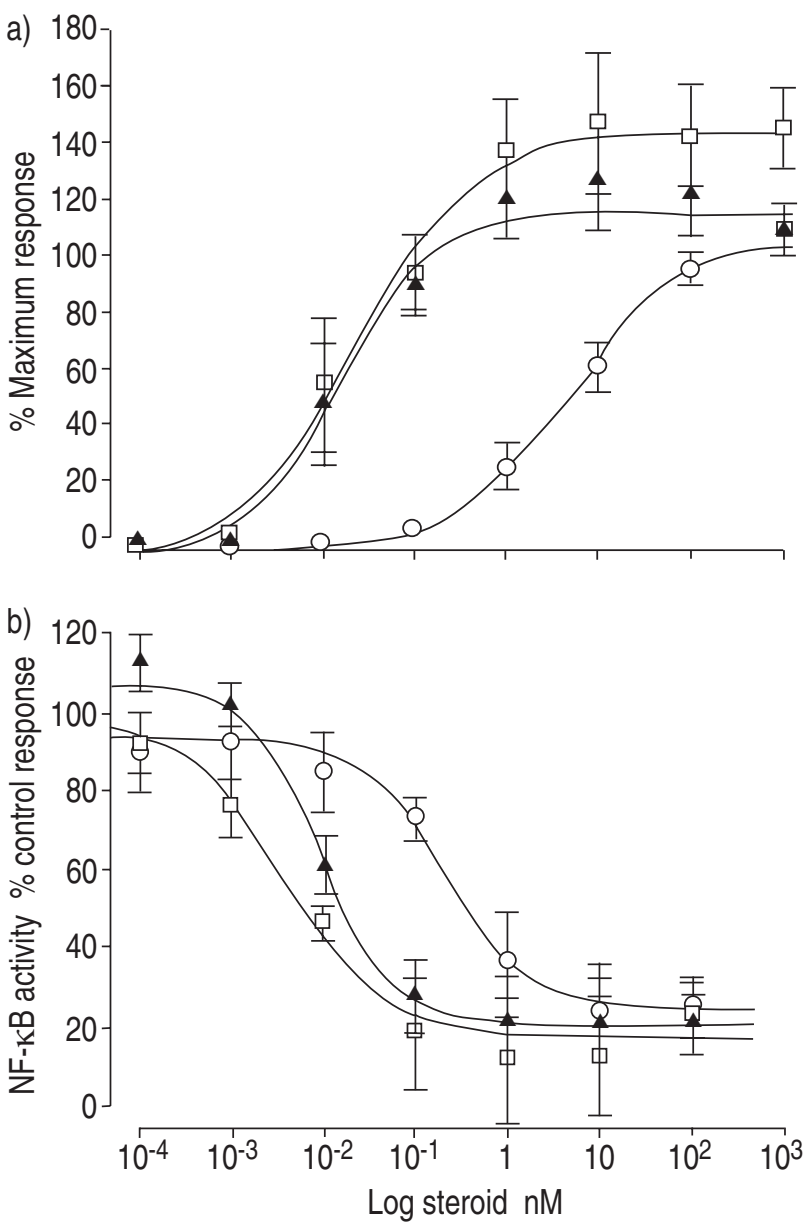

Fig. 1.-Corticosteroid effects on glucocorticoid receptor function. The level of reporter gene expression was measured in A549derived cell lines where the reporter was under the control of a) the long terminal repeat of the mouse mammary tumour virus and $b$ ) a nuclear factor $(\mathrm{NF})-\kappa \mathrm{B}$ responsive promoter. Cells were treated with indicated amounts of dexamethasone $(\bigcirc)$, fluticasone propionate $(\square)$ or mometasone furoate $(\boldsymbol{\Delta})$. To measure NF- $\kappa$ B activity, cells were stimulated with $0.5 \mathrm{ng} \cdot \mathrm{mL}^{-1}$ tumour necrosis factor (TNF)- $\alpha 1 \mathrm{~h}$ after the addition of steroid. Luciferase levels were measured $16 \mathrm{~h}$ after stimulation. Data were normalised to the maximal stimulation by a) dexamethasone $(5.1 \pm 0.7$-fold above basal) or b) TNF- $\alpha$ (3.8 \pm 0.84 -fold above basal). Results are the mean \pm SEM for three independent experiments.

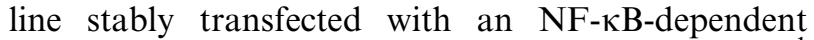
reporter construct. Stimulation with $0.5 \mathrm{ng} \cdot \mathrm{mL}^{-1}$ TNF- $\alpha$ induced a 3.8-fold increase in luciferase expression (data not shown). All three corticosteroids were able to repress TNF- $\alpha$-driven NF- $\kappa \mathrm{B}$ activation by similar amounts in a dose-dependent manner, with concentration values generating 50\% maximal inhibitory effect (IC50) of 4 pM (FP), 10 pM (MF) and $0.2 \mathrm{nM}$ (dexamethasone). Again, other steroid receptor ligands were unable to repress $\mathrm{NF}-\kappa \mathrm{B}$ reporter gene expression in these cells (data not shown).

The specificity of FP and MF for the GR was assessed. To measure activity at the progesterone receptor, T47D cells were used, a breast carcinoma cell line that naturally overexpresses the progesterone receptor and responds to progestins with an increase 
in cellular expression of alkaline phosphatase [23]. FP stimulated alkaline phosphatase expression in T47D cells, reaching $80 \pm 5 \%(\mathrm{p}<0.01)$ of the maximal response to progesterone with an EC50 of $1 \mathrm{nM}$ (fig. 2a). MF was clearly a full agonist, and was more than an order of magnitude more potent than FP, with an EC50 of $50 \mathrm{pM}$ (fig. 2a). In contrast, dexamethasone could only stimulate alkaline phosphatase expression at concentrations $>1 \mu \mathrm{M}$, while oestradiol, aldosterone and testosterone were inactive (data not shown). The effects of progesterone, FP and MF could all be reversed by pretreatment of the cells with the progesterone receptor/GR antagonist RU486, demonstrating that the effects seen are receptor mediated (fig. 2b). Thus, both FP and MF are not
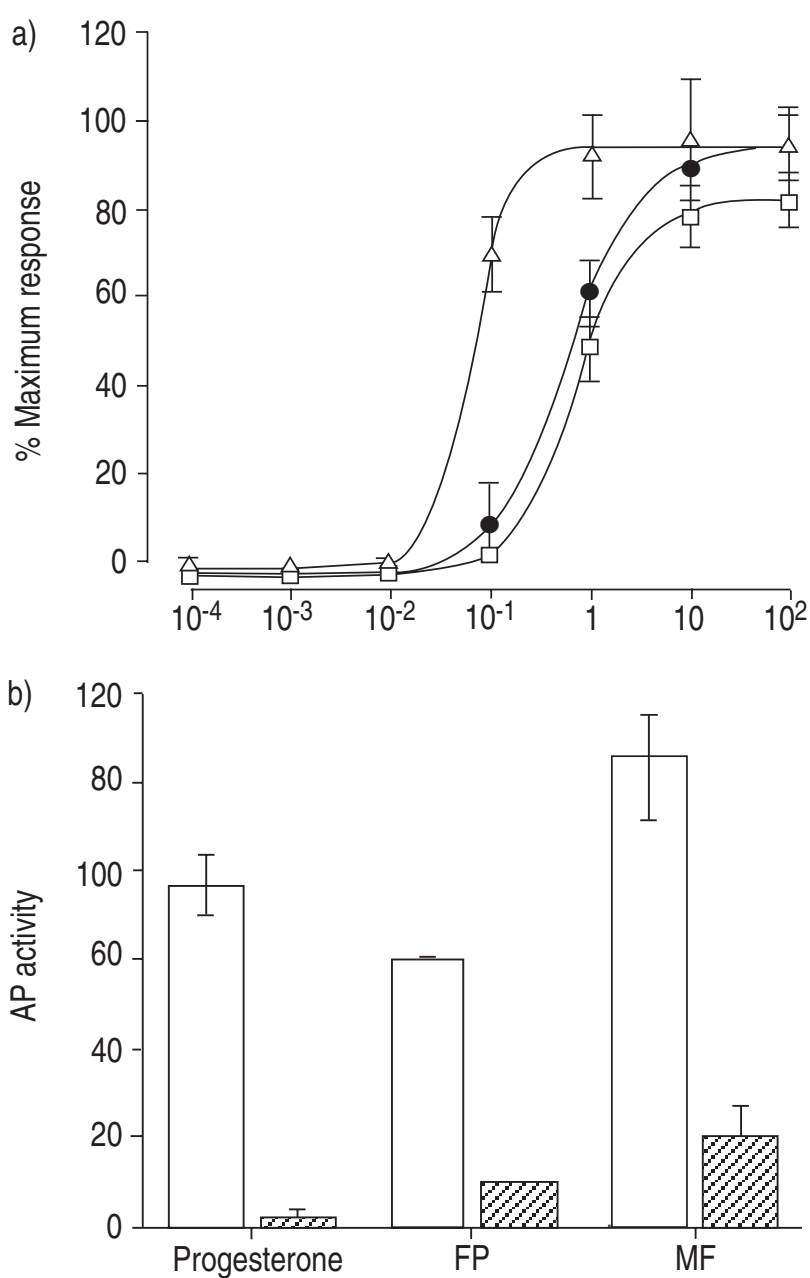

Fig. 2.-Activity of corticosteroids at the progesterone receptor. a T47D cells were stimulated for $16 \mathrm{~h}$ with indicated amounts of progesterone $(\bullet)$, fluticasone propionate $(\square)$ or mometasone furoate $(\triangle)$ and the amount of cellular alkaline phosphatase activity was measured. Data were normalised to the maximal stimulation by progesterone in each experiment which was $2.6 \pm 0.26$-fold above basal. Results are the mean \pm SEM for three independent experiments. b) T47D cells were treated with $(\mathbb{Z})$ or without $(\square) 50 \mathrm{nM}$ RU486 for $15 \mathrm{~min}$ prior to stimulation with $1 \mathrm{nM}$ steroid as indicated. Data were normalised to the response to $1 \mu \mathrm{M}$ progesterone in each assay. Results are the average of two independent experiments. FP: fluticasone propionate; MF: mometasone furoate; AP: alkaline phosphatase. pure corticosteroids, but have significant activity at the progesterone receptor.

Ishikawa cells, an endometrial carcinoma cell line, constitutively overexpress oestrogen receptors and respond to oestrogens with an increase in cellular expression of alkaline phosphatase, while ligands specific for other steroid receptors (including dexamethasone) are inactive [24]. FP and MF were both unable to stimulate alkaline phosphatase expression in Ishikawa cells (fig. 3a), and neither corticosteroid was able to antagonise the effects of oestradiol (fig. 3b), indicating that neither FP nor MF have any crossreactivity with oestrogen receptors in Ishikawa cells.

COS-1 cells, a simian fibroblast cell line, does not respond to any of the steroid ligands for nuclear
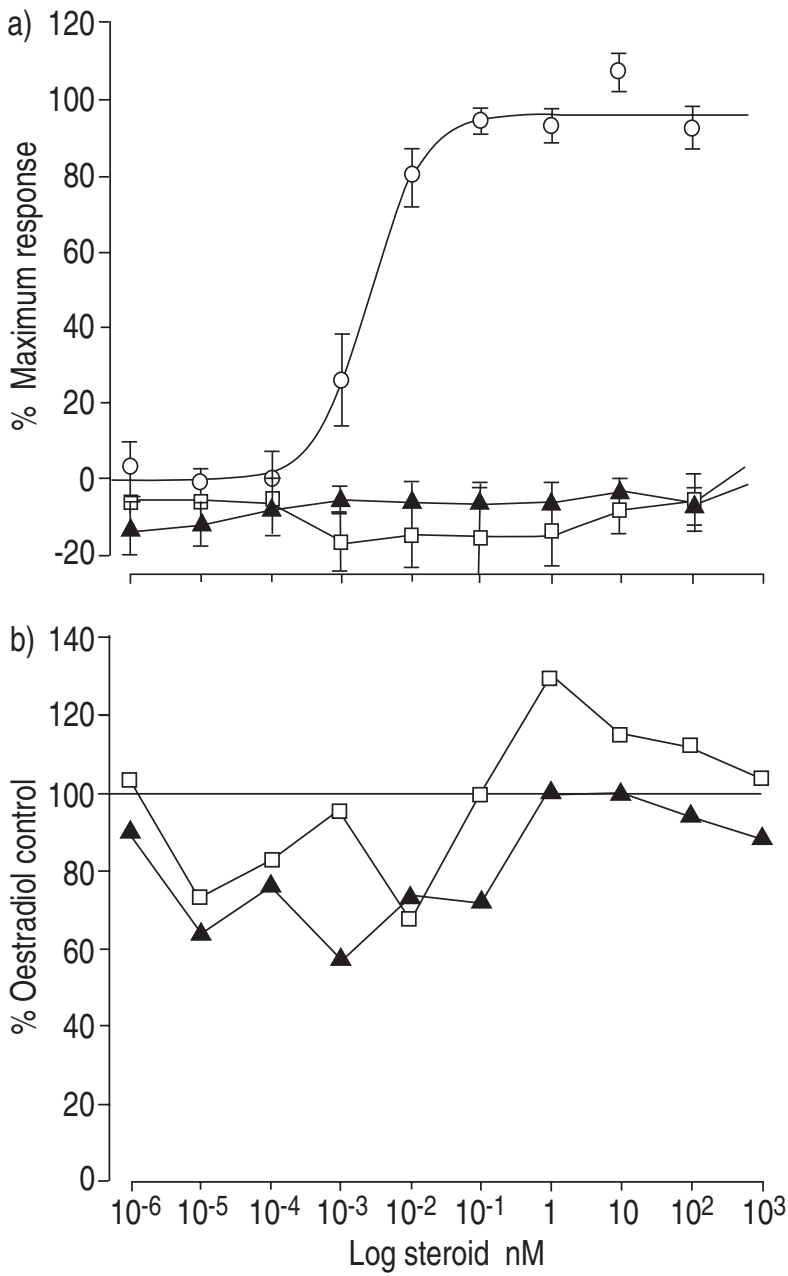

Fig. 3.-Activity of corticosteroids at the oestrogen receptor. a) Ishikawa cells were stimulated for $16 \mathrm{~h}$ with indicated amounts of oestradiol $(\bigcirc)$, fluticasone propionate $(\square)$ or mometasone furoate $(\boldsymbol{\Delta})$ and the amount of cellular alkaline phosphatase activity was measured. Data were normalised to the maximal stimulation by oestradiol in each experiment which was $1.7 \pm 0.4$-fold above basal. Results are the mean+SEM for three independent experiments. b) Ishikawa cells were treated with indicated amounts of fluticasone propionate $(\square)$ or mometasone furoate $(\boldsymbol{\Delta})$ for $1 \mathrm{~h}$ prior to the addition of $10 \mathrm{pM}$ oestradiol. The amount of cellular alkaline phosphatase activity was measured $16 \mathrm{~h}$ later. Data were normalised to the stimulation by oestradiol alone in each experiment, which was 1.5 -fold above basal. Results are the mean for two independent experiments that gave essentially identical results. 
receptors when transfected with a plasmid containing an MMTV-LTR-driven reporter gene (data not shown). However, if a plasmid coding for expression of the human GR was transfected along with the MMTV reporter, dexamethasone was able to stimulate reporter gene expression with an EC50 similar to that observed in A549 cells (2 nM; data not shown). This demonstrates that the COS-1 cells do not contain high levels of 11- $\beta$ hydroxysteroid dehydrogenase activity, which protects tissues that are mineralocorticoid targets from activation by glucocorticoids [25]. The MR agonist aldosterone was able to stimulate responses through transfected GR, but only at high concentrations (EC50 of $400 \mathrm{nM}$; data not shown).

In COS-1 cells, transiently transfected with a plasmid allowing expression of the human androgen receptor along with the MMTV reporter, the androgen receptor ligand, testosterone, was able to stimulate reporter gene expression with an EC50 of $0.6 \mathrm{nM}$ (fig. 4a). This activation could be prevented by pretreatment of the cells with the androgen receptor antagonist cyproterone (data not shown). Both FP and MF showed very little agonist activity at the androgen receptor, with neither reaching $>18 \%$ of the maximal response to testosterone (fig. 4a). Instead, both compounds acted as antagonists of the androgen receptor, although the concentrations at which this occurred were more than three orders of magnitude higher than their effects on the GR $(1.7 \mu \mathrm{M}$ and $70 \mathrm{nM}$ for $\mathrm{FP}$ and $\mathrm{MF}$, respectively; fig. 4b). Dexamethasone showed no activity at the androgen receptor at concentrations up to $1 \mu \mathrm{M}$ (data not shown).

COS-1 cells were also transiently transfected with a plasmid allowing expression of the human mineralocorticoid receptor along with the MMTV reporter. In these cells, the mineralocorticoid receptor ligand, aldosterone, potently stimulated an increase in reporter gene activity with an EC50 of $50 \mathrm{pM}$. In contrast, FP was unable to stimulate a response at concentrations as high as $1 \mu \mathrm{M}$ (fig. 5a). MF, however, induced partial activation of the mineralocorticoid receptor, generating $30 \%$ of the maximal response to aldosterone with an EC50 of $3 \mathrm{nM}$ (fig. 5a). Dexamethasone was a full agonist (EC50 of $10 \mathrm{nM})$, and the effects of aldosterone, dexamethasone and MF could all be blocked by pretreatment of the cells with the specific MR antagonist, spironolactone (data not shown). At high concentrations, FP acted as an antagonist of aldosterone in these cells, with an IC50 of $80 \mathrm{nM}$, while MF partially blocked aldosterone-stimulated responses at the same concentrations as it induced MR activity (60\% inhibition, IC 50 of $3 \mathrm{nM}$; fig. $5 \mathrm{~b}$ ). This indicates that while FP is a weak mineralocorticoid receptor antagonist, $\mathrm{MF}$ is a relatively potent partial agonist of the mineralocorticoid receptor.

\section{Discussion}

In this study, the authors have clearly demonstrated that MF and FP are essentially indistinguishable in their effects on the GR, in terms of potency of gene transactivation and transrepression [22, 25-27]. However, they have gone on to show that MF is
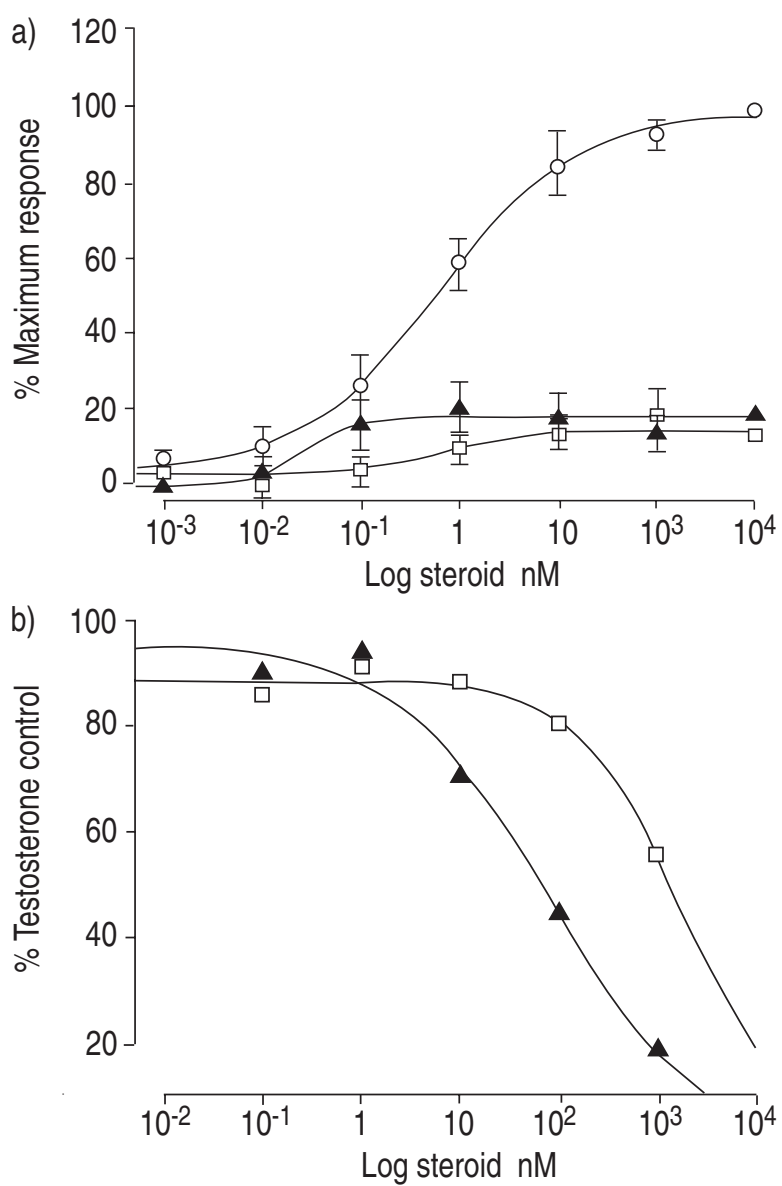

Fig. 4.-Activity of corticosteroids at the androgen receptor. COS1 cells were transiently transfected with a plasmid encoding expression of the human androgen receptor and a reporter plasmid containing the secreted placental alkaline phosphatase under the control of the long terminal repeat of the mouse mammary tumour virus. a) Transfected cells were stimulated for $16 \mathrm{~h}$ with indicated amounts of testosterone $(\bigcirc)$, fluticasone propionate $(\square)$ or mometasone furoate $(\boldsymbol{\Delta})$ and the amount of secreted alkaline phosphatase activity was measured. Data were normalised to the maximal stimulation by testosterone in each experiment which was $3.4 \pm 0.31$-fold above basal. Results are the mean \pm SEM for three independent experiments. b) Transfected cells were treated with indicated amounts of fluticasone propionate $(\square)$ or mometasone furoate $(\boldsymbol{\Delta})$ for $1 \mathrm{~h}$ prior to the addition of $6 \mathrm{nM}$ testosterone. The amount of cellular alkaline phosphatase activity was measured $16 \mathrm{~h}$ later. Data were normalised to the stimulation by testosterone alone in each experiment which was 3.2-fold above basal. Results are the mean for two independent experiments that gave essentially identical results.

significantly less specific for the GR than FP. First, MF was more than an order of magnitude more potent than FP as an agonist of the progesterone receptor, making it one of the most potent progestins observed. Secondly, MF was a relatively potent partial agonist of the mineralocorticoid receptor while FP was a pure antagonist with lower potency.

The side-effects reported to be associated with inhaled glucocorticoid use result from systemic exposure to the steroid despite topical administration. Both FP and MF have been developed to have pharmacokinetic profiles (lung retention, rapid metabolism) that should minimise such effects, but despite 

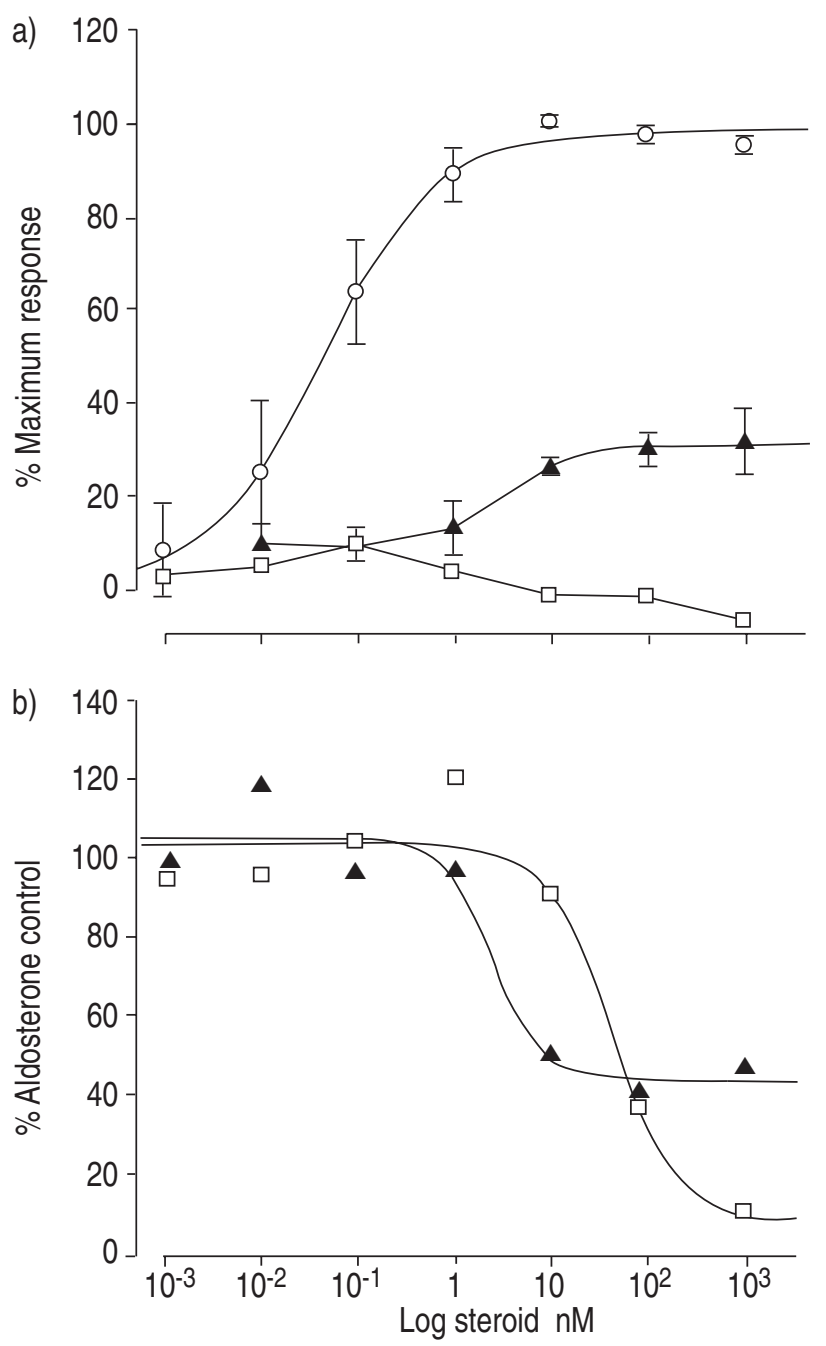

Fig. 5.-Activity of corticosteroids at the mineralocorticoid receptor. COS-1 cells were transiently transfected with a plasmid encoding expression of the human mineralocorticoid receptor and a reporter plasmid containing the secreted placental alkaline phosphatase under the control of the long terminal repeat of the mouse mammary tumour virus. a) Transfected cells were stimulated for $16 \mathrm{~h}$ with indicated amounts of aldosterone $(\bigcirc)$, fluticasone propionate $(\square)$ or mometasone furoate $(\boldsymbol{\Delta})$ and the amount of secreted alkaline phosphatase activity was measured. Data were normalised to the maximal stimulation by aldosterone in each experiment which was $2.5 \pm 0.3$-fold above basal. Results are the mean \pm SEM for three independent experiments. b) Transfected cells were treated with indicated amounts of fluticasone propionate $(\square)$ or mometasone furoate $(\boldsymbol{\Delta})$ for $1 \mathrm{~h}$ prior to the addition of $1 \mathrm{nM}$ aldosterone. The amount of cellular alkaline phosphatase activity was measured $16 \mathrm{~h}$ later. Data were normalised to the stimulation by aldosterone alone in each experiment which was two-fold above basal. Results are the mean for two independent experiments that gave essentially identical results.

extensive drug development effort, evidence of systemic exposure has still been reported [2, 28, 29]. Neither corticosteroid had any activity at the oestrogen receptor, and although both acted as antagonists of the androgen receptor, the concentrations at which this effect was observed were well above those which are physiologically relevant. Both FP and MF were agonists of the progesterone receptor. However, the effects of FP were relatively weak, such that at concentrations required to give $90 \%$ activation of the MMTV reporter $(100 \mathrm{nM}), \mathrm{FP}$ displayed negligible progesterone-like activity (5\%). In contrast, $\mathrm{MF}$ is more than an order of magnitude more potent than FP at the progesterone receptor such that the concentration response curves for the effects of MF on GR and progesterone receptor overlap. Thus, $100 \mathrm{nM}$ $\mathrm{MF}$, which gives the same response as $100 \mathrm{nM} \mathrm{FP}$ at the GR, also shows considerable activity at the progesterone receptor $(70 \%$ maximum; fig. $4 \mathrm{a})$. Therefore, if systemic exposure is sufficient to generate effects mediated through the GR (e.g. suppression of the hypothalamus-pituitary-adrenal axis [30]), it is highly likely that with MF the progesterone receptor is also activated, while with FP it would not be. Inappropriate activation of the progesterone receptor is likely to result in dysregulation of the oestrus cycle and/or a worsening of the symptoms of premenstrual tension. These effects may be more evident or severe in women with pre-existing difficulties. Clearly, excessive activation of progesterone receptors will ultimately have a contraceptive effect. The availability of MF and FP, which have identical activities at the GR, but very significant differences in activity at the progesterone receptor, should allow the design of clinical studies to determine whether these in vitro observations have any clinical relevance.

A similar argument can be made for the effects on the mineralocorticoid receptor, where FP acted as an antagonist with low potency $(80 \mathrm{nM})$, while $\mathrm{MF}$ behaved as a classical partial agonist with potency at the mineralocorticoid receptor $>10$-times higher than FP $(3 \mathrm{nM})$. While these concentrations are a little higher than those which stimulate GR, even small effects on the mineralocorticoid receptor may lead to a disturbance of the homeostatic mechanisms regulating electrolyte balance that could result in clinical manifestations following long-term corticosteroid use or during corticosteroid withdrawal.

The data presented in this study raise significant new issues when considering the potential for sideeffects with the new generation inhaled corticosteroids. It is clear that if systemic effects resulting from the activity at the glucocorticoid receptor can be observed, then there is a much greater chance of also seeing effects related to the progesterone and mineralocorticoid receptor when using mometasone furoate compared with fluticasone propionate. It is likely that different individuals or groups may be more or less susceptible to alterations in these important hormonal systems, and the effects may become much more significant during prolonged use. Both prospective and retrospective clinical studies are required to ascertain the significance of these findings, but in the future these considerations may influence the decision of which corticosteroid to prescribe in any circumstance, in order to achieve the best possible safety profile for the patient.

\section{References}

1. Williams DM. Clinical considerations of the use of inhaled corticosteroids for asthma. Pharmacotherapy 2001; 21: 38S-48S. 
2. Wong CA, Walsh LJ, Smith CJ, et al. Inhaled corticosteroid use and bone-mineral density in patients with asthma. Lancet 2000; 355: 1399-1403.

3. Allen DB. Do intranasal corticosteroids affect childhood growth? Allergy 2000; 55: Suppl. 62, 15-18.

4. Pauwels RA, Löfdahl CG, Laitinen LA, et al. Longterm treatment with inhaled budesonide in persons with mild chronic obstructive pulmonary disease who continue smoking. European Respiratory Society Study on Chronic Obstructive Pulmonary Disease. N Engl J Med 1999; 340: 1948-1953.

5. Cumming RG, Mitchell P, Leeder SR. Use of inhaled corticosteroids and the risk of cataracts. $N$ Engl J Med 1997; 337: 8-14.

6. Faul JL, Tormey W, Tormey V, Burke C. High dose inhaled corticosteroids and dose dependent loss of diabetic control. BMJ 1998; 317: 1491.

7. Johnson M. Development of fluticasone propionate and comparison with other inhaled corticosteroids. J Allergy Clin Immunol 1998; 101: S434-S439.

8. Fish JE, Karpel JP, Craig TJ, et al. Inhaled mometasone furoate reduces oral prednisone requirements while improving respiratory function and health-related quality of life in patients with severe persistent asthma. J Allergy Clin Immunol 2000; 106: 852-860.

9. Kemp JP, Berkowitz RB, Miller SD, Murray JJ, Nolop K, Harrison JE. Mometasone furoate administered once daily is as effective as twice-daily administration for treatment of mild-to-moderate persistent asthma. J Allergy Clin Immunol 2000; 106: 485-492.

10. Corren J. Intranasal corticosteroids for allergic rhinitis: how do different agents compare? J Allergy Clin Immunol 1999; 104: S144-S149.

11. Lumry WR. A review of the preclinical and clinical data of newer intranasal steroids used in the treatment of allergic rhinitis. J Allergy Clin Immunol 1999; 104: S150-S158.

12. Hollenberg SM, Weinberger C, Ong ES, et al. Primary structure and expression of a functional human glucocorticoid receptor cDNA. Nature 1985; 318: 635-641.

13. Beato M, Klug J. Steroid hormone receptors: an update. Hum Reprod Update 2000; 6: 225-236.

14. Rajapandi T, Greene LE, Eisenberg E. The molecular chaperones Hsp90 and Hsc70 are both necessary and sufficient to activate hormone binding by glucocorticoid receptor. J Biol Chem 2000; 275: 22597-22604.

15. Ray A, Siegel MD, Prefontaine KE, Ray P. Antiinflammation: direct physical association and functional antagonism between transcription factor NF- $\mathrm{BB}$ and the glucocorticoid receptor. Chest 1995; 107: $139 \mathrm{~S}$.

16. Konig $\mathrm{H}$, Ponta $\mathrm{H}$, Rahmsdorf HJ, Herrlich $\mathrm{P}$. Interference between pathway-specific transcription factors: glucocorticoids antagonize phorbol esterinduced AP-1 activity without altering AP-1 site occupation in vivo. EMBO J 1992; 11: 2241-2246.
17. Groner B, Fritsche M, Stocklin E, et al. Regulation of the trans-activation potential of STAT5 through its DNA-binding activity and interactions with heterologous transcription factors. Growth Horm IGF Res 2000; 10: 15-20.

18. Biola A, Andreau K, David M, et al. The glucocorticoid receptor and STAT6 physically and functionally interact in T-lymphocytes. FEBS Lett 2000; 487: 229233.

19. Barnes PJ, Adcock I. Anti-inflammatory actions of steroids: molecular mechanisms. Trend Pharmacol Sci 1993; 14: 436-441.

20. Cato AC, Wade E. Molecular mechanisms of antiinflammatory action of glucocorticoids. Bioessays 1996; 18: 371-378.

21. Atsuta J, Plitt J, Bochner BS, Schleimer RP. Inhibition of VCAM-1 expression in human bronchial epithelial cells by glucocorticoids. Am J Respir Cell Mol Biol 1999; 20: 643-650.

22. Stellato C, Atsuta J, Bickel CA, Schleimer RP. An in vitro comparison of commonly used topical glucocorticoid preparations. J Allergy Clin Immunol 1999; 104: 623-629.

23. Di Lorenzo D, Albertini A, Zava D. Progestin regulation of alkaline phosphatase in the human breast cancer cell line T47D. Cancer Res 1991; 51: 4470-4475.

24. Littlefield BA, Gurpide E, Markiewicz L, McKinley B, Hochberg R. A simple and sensitive microtiter plate estrogen bioassay based on stimulation of alkaline phosphatase in Ishikawa cells: Estrogenic action of $\Delta^{5}$ adrenal steroids. Endocrinology 1990; 127: 2757-2762.

25. Diederich S, Quinkler M, Burkhardt P, Grossmann C, Bahr V, Oelkers W. 11ß-hydroxysteroid-dehydrogenase isoforms: tissue distribution and implications for clinical medicine. Eur J Clin Invest 2000; 30: 21-27.

26. Smith CL, Kreutner W. In vitro glucocorticoid receptor binding and transcriptional activation by topically active glucocorticoids. ArzneimittelForschung 1998; 48: 956-960.

27. Jaffuel D, Demoly P, Gougat C, et al. Transcriptional potencies of inhaled glucocorticoids. Am J Respir Crit Care Med 2000; 162: 57-63.

28. Harrison TW, Wisniewski A, Honour J, Tattersfield AE. Comparison of the systemic effects of fluticasone propionate and budesonide given by dry powder inhaler in healthy and asthmatic subjects. Thorax 2001; 56: 186-191.

29. Affrime MB, Kosoglou T, Thonoor CM, Flannery BE, Herron JM. Mometasone furoate has minimal effects on the hypothalamic-pituitary-adrenal axis when delivered at high doses. Chest 2000; 118: 15381546.

30. Crim C, Pierre LN, Daley-Yates PT. A review of the pharmacology and phamacokinetics of inhaled fluticasone propionate and mometasone furoate. Clin Therapeut 2001; 23: 1339-1354. 